\title{
Feet and hands of the army
}

\author{
RUTH HOLLAND
}

There was a story once about a rather ill tempered conductor (orchestral, not on the buses) who married an opera singer with a plain face, no figure, and the voice of an angel. Alone together one evening they sat in silence until the maestro, after glaring at his wife for some minutes, barked out, "Sing, damn you!"

I never expected to have that kind of relationship with a book; but I don't think I have ever before shared a pillow with one that had so fine a theme locked in such an unprepossessing form-a kind of Hardback of Notre Dame. The Carrier Corps is made up of photocopies of typewritten pages (referred to rather grandly in the trade as camera ready copy); some of these pages are unrelieved. blocks of thick black type, others are blurred and dimly discernible, like the view from the 7.42 Euston to Rugby on a wet November morning; the photographs are smudgy and poorly defined, and evidence of editing and proof reading is hard to come by. It costs £38.50. Sing, damn you!

What it sings is not arms and the man but army supplies and the men who carried them. Carried them on their heads, in loads of $50 \mathrm{lb}$ or more, through harsh country in extremes of climate, far from their homes, often ill fed and ill treated, and dying in their thousands from disease-all in a war that was nothing to do with them. This is the story of the Africans who served as porters in the Carrier Corps in the East African campaign of the first world war; and it is a story worth telling.

\section{Unreadiness of all}

From Hannibal's elephants to the battery mules animals were the usual means of transporting military supplies until modern times, and in so far as they seem to have thought about it at all, the planners in the War Office intended to use them in the campaign in East Africa. But with the characteristic inability of their caste to see further than the ends of their noses they had overlooked a basic problem: the tsetse fly. In the early days of the campaign mounted troops and convoys of oxen and mule drawn supplies made their way south towards German East Africa from the East African Protectorate, as it then was. When they reached the tsetse belt that stretches across modern Tanzania the animals perished. What few roads there were soon became impassable to motor traffic; only the carriers could get through:

Dead mules and donkeys and even dead carriers littered the road on each side in various stages of putrefaction ... the road ran through the worst sort of stinking black mud.... The state of the road explained for iself the shortage of rations.... In order to feed 3,000 native troops, Europeans and various departmental units, an army of at least 12,000 men had to be employed.

You begin to see why using porters for transporting supplies was not the first thing that sprang to the military mind: it needs immensely complex organisation and is, in modern managementspeak, labour intensive to say the least. Animals need a few bags of meal or can graze where they stop; humans have to take their own food, cooking utensils, blankets, and so on. A marching song of the Baganda carriers went: "We are the porters who carry the food, of the porters who carry the food, of the porters who carry the food." Which about sums it up.

Because nobody had been prepared for it the organisation of all these men was started from scratch. At first it came under the civil authorities, but there was no central directorate to lay down ration scales or rules for management. Consequently there was chaos, with men being appropriated by the military authorities without notice to the carriers' organisers, and others deserting or transferring from one company to another so that nobody knew where they were:
Provisions and payment were haphazard at best. The men were recruited from all over the protectorate, and they travelled far away from their homelands. This caused problems not appreciated by some white settlers, who thought that all Africans were the same and ate the same food, although:

Europeans closely acquainted with Africans knew that they were not adaptable to climate, resistant to disease, or easy to feed. There is a difference between the hot coastal or Lake regions and the cool highlands where night frosts may occur at over 7,000 feet. 'Highland people are not resistant to malaria, from which Kikuyu migrants to the coast suffered, as well as dysentery. People used to warm climates would catch pneumonia in the highlands. Bacillary dysentery was endemic among the Nyanza tribes, but south of the Central Railway in German East Africa the amoebic type was to prove prevalent. This was the greatest menace to the carriers, and was known to be brought on by unsuitable food.

Fortunately for the carriers-and for the success of the campaign - the organisation of the corps was put on to a military footing under the Military Labour Bureau, which was in the charge of an able and conscientious man, Oscar F Watkins. An Oxford classics graduate, Watkins had first come to East Africa in 1908 and had served in the Boer War and in the mounted police in South Africa, where he had seen the introduction of fingerprinting. It was this alone, he claimed, that enabled him to keep track of hundreds of thousands of men, only a tiny number of whom could even sign their names. At its peak the Military Labour Bureau was the largest unit in the East African Force, with over 200 officers, about 600 British other ranks and over 100000 men. Watkins arranged for their medical inspection, the provision of their equipment, their pay, and their deployment over ever lengthening lines of communication in unfamiliar territory, and at the end of the campaign for their return

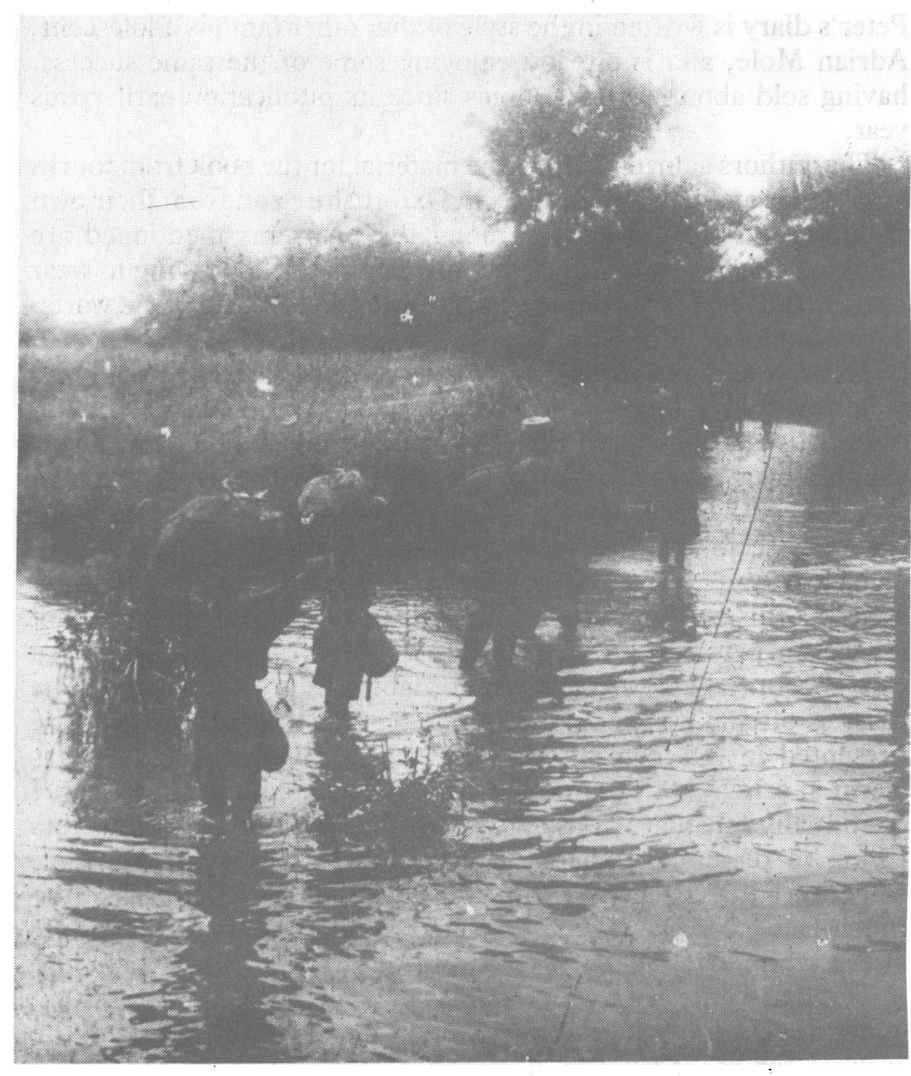

Roads soon became impassable.
Imperial W/ar Muscum. 
to their homes. During all this time he was fighting two campaigns, the second being against his own army colleagues and the excessive demands they made on the carriers. His achievement in creating and running an organisation for which there was no precedent, successfully handling vast numbers of men and almost equally vast sums of public money, was outstanding - and unrecognised. He never rose above the rank of lieutenant colonel, and at the end of the war was regarded as being too "pro-Native" to be suitable for a civil appointment as chief native commissioner.

\section{Bishop's move}

Watkins's increasing frustration with his superiors comes through clearly in his letters both to them and to his friends. The carriers, being illiterate, have left no written comment on their experiences, but Geoffrey Hodges managed to trace several veterans of the campaign who told him what they remembered, and their laconic statements run through the book as a muted counterpoint to the harsh theme of historical fact, giving a glimpse of the kind of men they were who were able to show such endurance and courage: down to earth, humorous, dignified, and without rancour.

One of the few pieces of evidence written in an African hand is rather surprising:

Truly our Lord Bishop is a great man! Did he not call us and gather us all together? Did he not drill us, and go for marches with us every day?... Truly he is a great man, for he came over the sea with us, and when we reached the mainland he marched with us, he slept with us, he ate with us, and when we laid down at night, did he not pray with us? And when we arose in the morning, did he not pray with us again?

The great man in question was Frank Weston, Bishop of Zanzibar, a high churchman who arraigned four fellow bishops for heresy, treated the Africans as his children; and regarded the war as the result of the sins of Europe. In 1916, when the British began to overrun German East Africa they recruited more porters, both in occupied territory and in Zanzibar. When the bishop protested against their methods he was challenged to do his own recruiting. In a few weeks he had 560 men, whom he drilled and commanded himself. A strict disciplinarian, he looked after his men and understood their difficulties. "The man," he wrote, "who has not had to do extra miles beyond his promised halting place, under tropical sun, has yet much to learn of what a broken spirit really means." The porters had to be rested,

otherwise men fall out and get lost or run away, or get overtired and ill. And to rest a column of 1,000 carriers in single file, or at best in double file, takes time; with the result that two and a half miles an hour is very fast, and one and a half is not unknown ... the stronger men get in well ahead of the last men, whose job it is to urge on the tired, look out for dropped loads, and gather up the sick. If there be a more weary work than coming last of such a column on a march of fifteen miles, I have not yet seen, heard or read of it. Yet it is not unuseful. Our men did very well on this particular work. We made a record for the journey both in time and accuracy. That is, we got our loads there quicker than other porters, and we got them all there. I gather this was not common.

After several successful journeys with his unit Weston fell sick with a high fever and was put on a boat for Zanzibar, but he refused to land without his men and returned to Dar es Salaam to fetch them home. A medical officer who examined them reported:

It was very pleasant to see in what good condition they were. This was due to the great care that the bishop had taken of his men. He had seen that they were properly treated, and this, I regret to say, was not always the case.

\section{Back again}

One reason for its not always being the case was the enormous increase in the number of carriers during the campaign. In the early days each corps had its own doctor, but as the numbers grew the men became separated from their doctors as well as from their

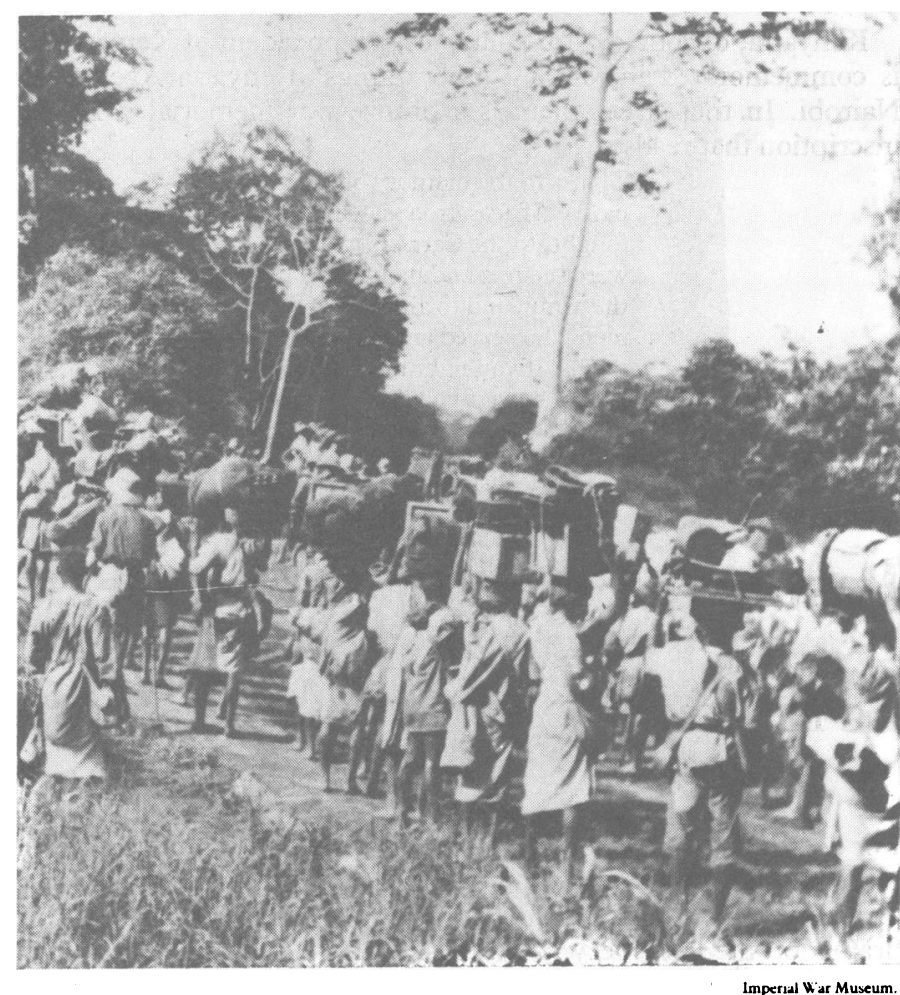

To rest a column of 1000 carriers ... takes time.

officers. If they were sick or wounded they had to depend on the medical officer of the post they happened to be at. A hard pressed MO might well give precedence to soldiers over carriers, and to white over black-thus making a carrier doubly sure of a place at the back of the queue, regardless of the seriousness of his complaint. Carriers were in fact not often wounded, most of the deaths being from disease: dysentery, pneumonia, malaria, smallpox, meningitis, and, at the end of the war, Spanish flu, which "seemed like a final visitation of God to the suffering people: 'He was angry because the young men had allowed themselves to be taken away to perish in the Europeans' war."'

Returning carriers often infected their villages with diseases contracted during the campaign. They did not, however, according to Geoffrey Hodges, bring back with them any revolutionary political ideas inspired by what they had been through. The old servicemen were unanimous that they had not discussed politics: "We hadn't much to talk of because there was no time. ... We were not politicians then .... What was worrying us was the war." To some extent the shared experience of war had made blacks and whites revise their opinions of each other: the blacks had seen that the supposedly all powerful Europeans could also be subject to disease, fear, and despair; the whites gained a new respect for the Africans_-one colonel in Nairobi, seeing a battalion of the King's African Rifles march by, exclaimed: "I take my hat off to these men; they do not know what fear means; they have won the war for us in East Africa." But these changes don't seem to have gone very deep: mostly the carriers settled down to resume their lives as best they could, and the white settlers went on pressing for more land for themselves, crown colony status for the protectorate, and compulsory labour and lower wages for the Africans. When political protests did come they came not from returned servicemen but from the Africans who had stayed at home and who were therefore more aware of what was going on in their own districts; they also tended to be the more literate, who had not been conscripted because they were in reserved occupations. Jomo Kenyatta, for instance, was in the public works department, and Harry Thuku, one of the early protest leaders, who worked on the Leader newspaper, was not allowed to go to war because as machine man and compositor he alone knew how to print maps and sketches of war positions. He was later arrested and deported because of his political activities. 
Kenyatta, of course, ultimately became president of Kenya, and is commemorated in, among other things, Kenyatta Avenue in Nairobi. In that street there is a bronze war memorial, with an inscription that reads:

This is to the memory of the native African troops who were the feet and hands of the army, and to all other men who served and died. If you fight for your country even if you die, your sons will remember your name. fought, to the Carriers who

The words are by Kipling, and the carriers' story is one to which he could perhaps have done justice. Geoffrey Hodges is not exactly in the Kipling class (who is?) but his enterprising researches have produced something new and valuable - a record which ensures that, if the individual carriers' names are not well remembered, at least the part they played in East African - and European-history is not forgotten.

Contributions in Comparative Colonial Studies. No 18. "The Carrier Corps. Military Labor in the East African Campaign 1914-1918." $G$ Hodges. (Pp 272; figs; £38.50.) New York: Greenwood Press, 1986. ISBN 0-313-24418-9.

\section{Pestilence stricken multitudes}

\author{
P G BENSON
}

For doctor and layman alike, smallpox held and still holds a special place in the rogues' gallery of disease. Until its eradication and the arrival of AIDS probably only the plague has been feared more. The drama of the discovery of vaccination, the controversies over variolation, and the debate on the virology have produced a considerable mass of medicohistorical publications. Most schoolchildren know the story of Jenner. Yet despite this little has been written about the social effects of smallpox, and it is this that J R Smith has attempted to do in The Speckled Monster.

In a sense he is lucky with his disease for the classic signs, symptoms, and infectivity of smallpox seem rarely mistaken and had been long known and feared. This enables the author to quote confidently many primary records and accounts from Essex, where he works as senior archivist. Indeed, it was his discovery of so much interesting material that persuaded him to expand his book into a more general study taking 1670 as his starting point. After an introductory chapter he considers the development of variolation with special reference to Daniel Sutton, and then describes the transition to vaccination with its rise and fall, and finally gives an account of the location and use of Essex pest houses and smallpox hospitals.

Using this wealth of material $\mathrm{Mr}$ Smith has managed to negotiate relatively unscathed the minefield that awaits the non-medical author writing about medical matters. He has very sensibly avoided the arcane arguments about the exact nature of vaccines used at various times, the true nature of cowpox, etc. In fact if I have a general criticism of the book it is that the author has felt it necessary to graft on to his excellent material stark clinical facts that do not help his exposition and are sometimes dubious. The description of ten "types" of smallpox is redundant and medically arguable. The glossary of medical terms is so over simplified as to be misleading, and the layman could happily and profitably ignore the jargon, which up to the nineteenth century has to be interpreted carefully anyway. Medical cause and effect is always difficult, and to attribute Josiah Wedgwood's amputation for probable tuberculosis of the knee to an attack of smallpox some $\mathbf{3 0}$ years previously is highly questionable. Other minor cavils are that the influence of Daniel Sutton (albeit a son of Essex) is overstressed and I wish that the ugly word "inoculee" could have been avoided.

Though a large portion of the book details splendid accounts of the days of early variolation and vaccination, it is the section from 1840 onwards which is of most new interest and importance with records of later outbreaks and the development (particularly in Essex) of isolation and smallpox hospitals. The part played by a fanatical religious sect, for example, who aptly named themselves "The Peculiar People" and by refusing vaccination caused the spread of several distinct outbreaks, is particularly fascinating and instructive. And it is salutary to be reminded that though by the late 1940 s it was being realised that mass vaccination was statistically

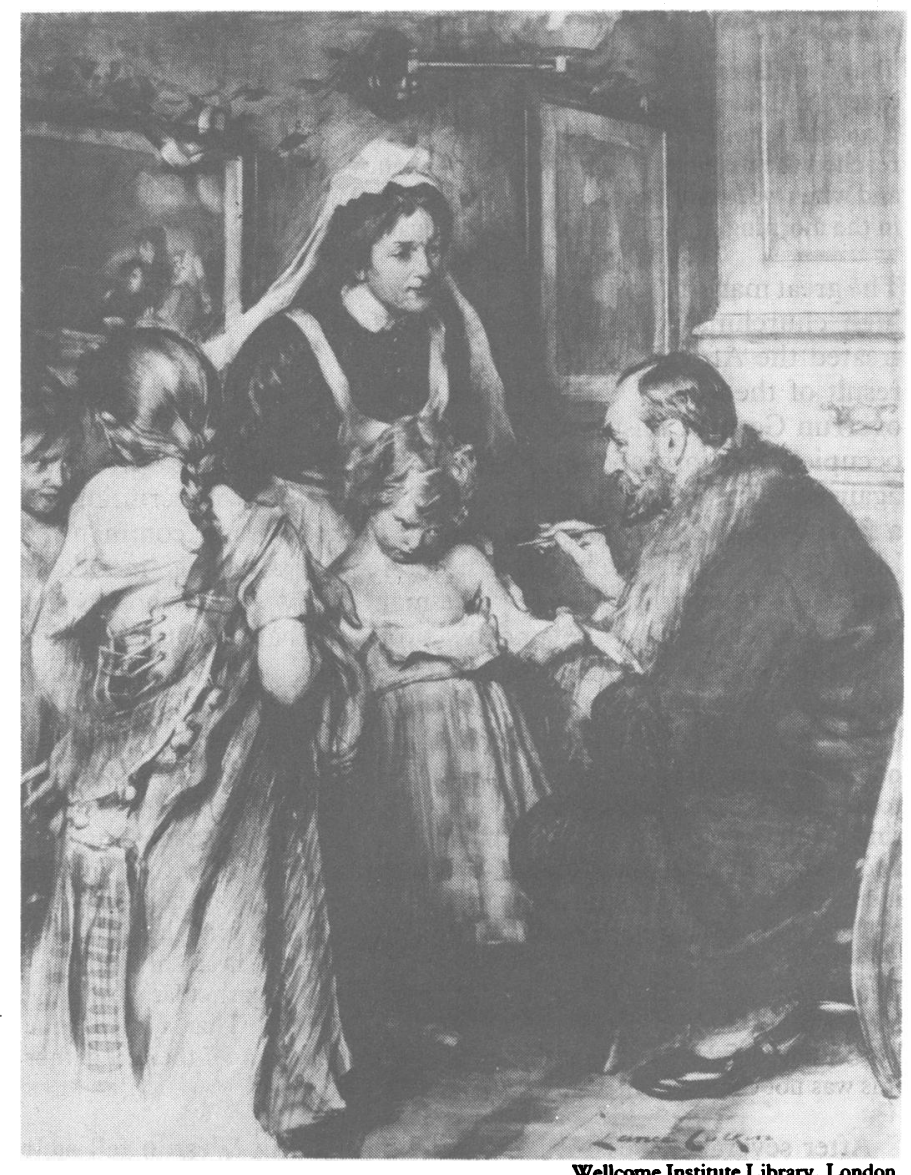

The public vaccinator. Gouache by Lance Calkin.

more dangerous than the disease itself, the Ministry of Health continued to advocate it into the 1960 s.

The Speckled Monster is well produced and printed and bristling with notes and references, and it has a useful, if very selective, bibliography. Let us hope that smallpox stays merely the subject of worthwhile historical books like this and that the pool of potentially mutagenic pox viruses in monkeys, camels, gerbils and the like stays there.

The Speckled Monster. Smallpox in England, 1670-1970, with Chelmsford: Essex Record Office, 1987. ISBN 0-900360-68-2. Particular Reference to Essex. J R Smith. (Pp 220; £14.95.) 